Case Report

\title{
BIFID TONGUE AND CLEFT PALATE: A RARE CONGENITAL MALFORMATION
}

\author{
I Gusti Ayu Putri Purwanthi', Agus Roy Rusly Hariantana Hamid ${ }^{1}$, I Gusti Putu Hendra Sanjaya1, \\ I Made Suka Adnyana ${ }^{1}$, Nyoman Siska Ananda ${ }^{1}, \&$ Gede Wara Samsarga ${ }^{1}$
}

1. Division of Plastic Reconstructive and Aesthetic Surgery, Department of Surgery, Faculty of Medicine Udayana University / Sanglah General Hospital Bali

\begin{abstract}
Background: Congenital bifid tongue without other craniofacial abnormalities is a very rare malformation. Here, we discuss a case of the bifid tongue with cleft palate, reported in a 7-month-old girl with no other syndromes or craniofacial abnormalities.

Case Reports: This case report described a 7-month-old girl with an anterior bifid tongue, separated medially by a soft, solitary sublingual mass measuring $3 \mathrm{~cm} \times 2 \mathrm{~cm}$ in size. There was also an associated incomplete cleft palate. A soft solitary mass measuring $2 \mathrm{~cm} \times 2 \mathrm{~cm}$ in size was also seen within the cleft palate.

Results: Computed facial tomography (CT) revealed a midline hard palate defect with an intact alveolar process of the maxilla. Pedunculated cystic lesion suspected with epulis was noted to arise on premaxillary alveolar mucosa. Excision of the tongue and hard palate mass and repair of the bifid tongue were done.

Summary: Congenital bifid tongue with a cleft is a very rare malformation with different variations. Early surgical intervention is critical to prevent speech impairment and swallowing disorders. A multidisciplinary approach, including well-planned staged operations and rehabilitation, is important to achieve favorable outcomes.

Keywords: Bifid Tongue; Cleft Tongue; Cleft Palate; Congenital Anomaly
\end{abstract}

\section{ABSTRAK}

Latar Belakang: Lidah bifida kongenital tanpa kelainan kraniofasial lainnya merupakan malformasi yang sangat jarang terjadi. Di sini, kami membahas kasus lidah bifida dengan celah langit-langit pada anak perempuan berusia 7 bulan tanpa sindrom atau kelainan kraniofasial lainnya.

Laporan Kasus: Laporan kasus ini menggambarkan anak perempuan berusia 7 bulan dengan lidah bifida anterior yang dipisahkan oleh massa sublingual soliter lunak berukuran $3 \mathrm{~cm} \times 2 \mathrm{~cm}$ pada bagian medial lidah. Terdapat juga sumbing langitan inkomplit pada pasien. Massa soliter lunak berukuran $2 \mathrm{~cm} \times 2 \mathrm{~cm}$ terlihat di antara celah langitan.

Hasil: Hasil Computed facial tomography (CT) menunjukan defek pada bagian midline palatum durum dengan processus alveolaris maksila yang intak. Lesi kistik bertangkai yang dicurigai epulis ditemukan muncul pada mukosa alveolar premaksila. Eksisi massa lidah dan palatum durum serta perbaikan lidah bifida dilakukan.

Ringkasan: Lidah bifida kongenital dengan sumbing merupakan malformasi yang sangat jarang dengan variasi yang berbeda. Intervensi bedah dini sangat penting untuk mencegah gangguan bicara dan gangguan menelan. Pendekatan multidisiplin termasuk operasi dan rehabilitasi yang terencana dengan baik adalah penting untuk mencapai hasil yang menguntungkan.

Kata Kunci: Lidah Bifid; lidah sumbing; Celah langit-langit; Anomali Bawaan

Conflicts of Interest Statement:

The Author (s) listed in this manuscript declare the absence of any conflict of interest on the subject matter or materials discussed. 


\section{INTRODUCTION}

The bifid tongue is a rare congenital malformation commonly associated with syndromes and is rarely an isolated case. The most common syndromes related are Tessier type 30 craniofacial cleft and Oro-Facial-Digital Syndrome (OSDS). Congenital bifid tongue with cleft palate is an infrequent entity with different variations reported worldwide. Review articles of 37 cases by Hiradfar et al. (2015) described that $62 \%$ of patients are females and $43 \%$ are associated with cleft palate. Sometimes, hamartoma or tumor (teratoma) may also be present with bifid tongue (1).

The tongue is a muscular organ with various functions, including assisting deglutition, articulation, and taste. The bifid language could happen with multiple degrees of severity and functional disturbance, from asymptomatic to respiratory, swallowing, and speech problems. Early surgical intervention is recommended to prevent complications at later ages, especially speech and swallowing disorders (2). This article reports one case of the congenital bifid tongue associated with cleft palate with no other syndromes or craniofacial abnormalities.

\section{CASE REPORT}

The 7-month-old girl was presented with anterior bifid tongue with secondary palate cleft and pedunculated cystic lesion over her tongue and palate (Figure 1A) since birth. She was born at 38 weeks gestation via spontaneous vaginal delivery with a good Appearance, Pulse, Grimace, Activity, Respiration (APGAR) score. Her developmental milestones have been typical thus far. She was using a specialized cleft palate bottle, and no choking history was noted. There was no family history of the cleft or bifid tongue and antenatal abnormality during pregnancy.

The intraoral examination noted an anteriorly bifid tongue, separated medially by a soft, solitary pedunculated mass measuring $4 \mathrm{~cm}$ $x 3 \mathrm{~cm}$ in size. There was also an associated incomplete cleft palate. A soft solitary mass measuring $3 \mathrm{~cm} \times 2 \mathrm{~cm}$ in size was also found within the cleft palate. A Computerized tomography (CT) scan examination showed an incomplete palatoschisis with a pedunculated cystic lesion in premaxillary alveolar mucosa suspect epulis with suspect congenital bifid tongue (Figure 1).

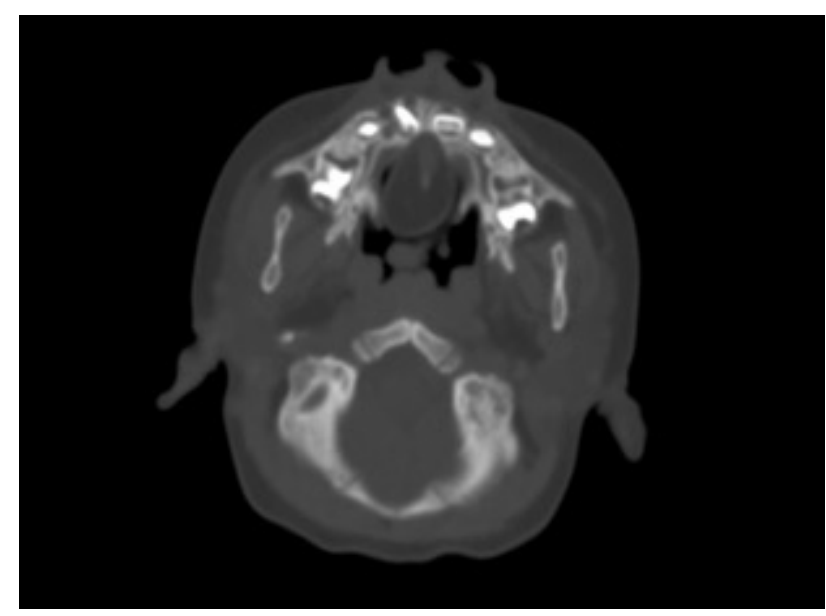

Figure 1. Axial Ct Scan image shows an incomplete palatoschisis with a pedunculated cystic lesion in premaxillary alveolar mucosa.

Excision of the sublingual and palate mass and the reconstruction of the bifid tongue were done under anesthesia via oral intubation (Figure 2 and 3 ). The edge of the bifid tongue was excised through and through, followed by primary closure of the mucosa and muscle layers with absorbable sutures. The frenulum and the sublingual ventral defect were closed in a ZPlasty fashion. The excised masses were sent to the histopathology examination.

The recovery period was uneventful, and the patient was discharged two days after surgery. Histopathology showed Pseudoepitheliomatous Hyperplasia (PEH) of the sublingual and palate tissue, focusing on squamous and periductal subepithelial inflammation. The surgical scar was favorable in the first month after surgery (Figure 4 ), and there were no feeding difficulties. The palatoplasty was planned six months after the first surgery. She was referred for speech therapy to assist her speech development according to her milestones. 

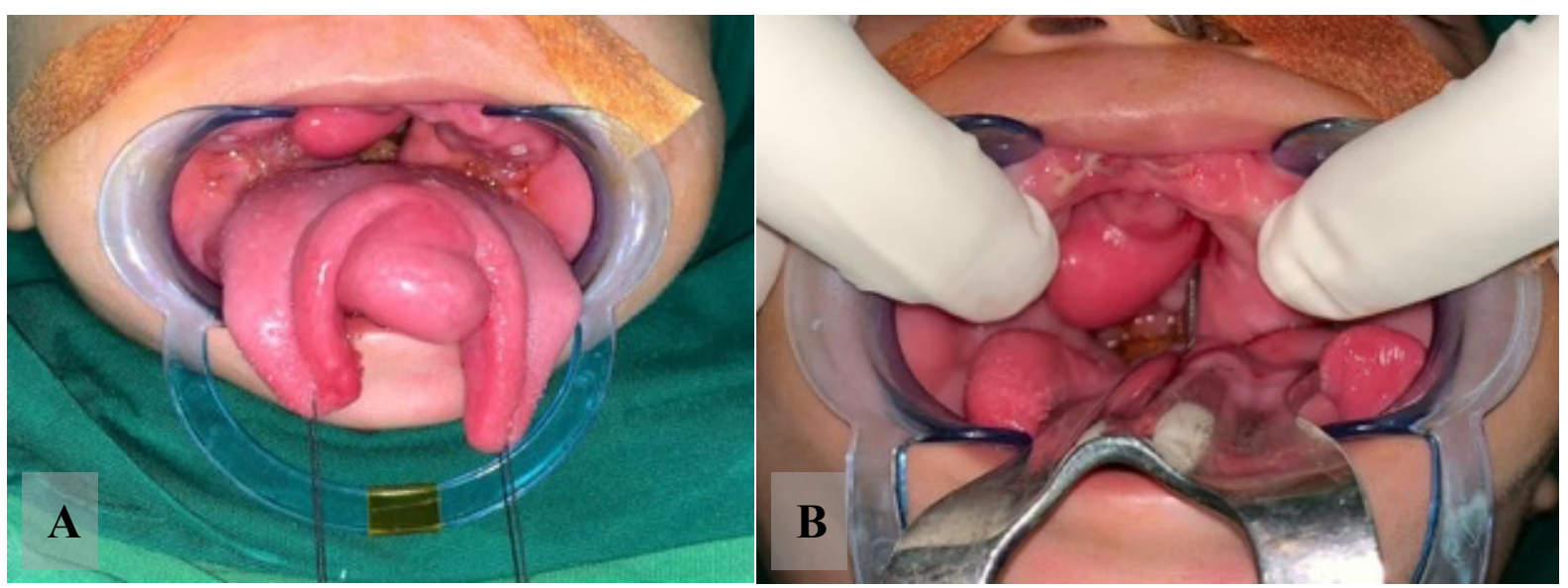

Figure 2. Preoperative picture of the A) Sublingual mass with bifid tongue, B) Palatal mass with secondary cleft palate.

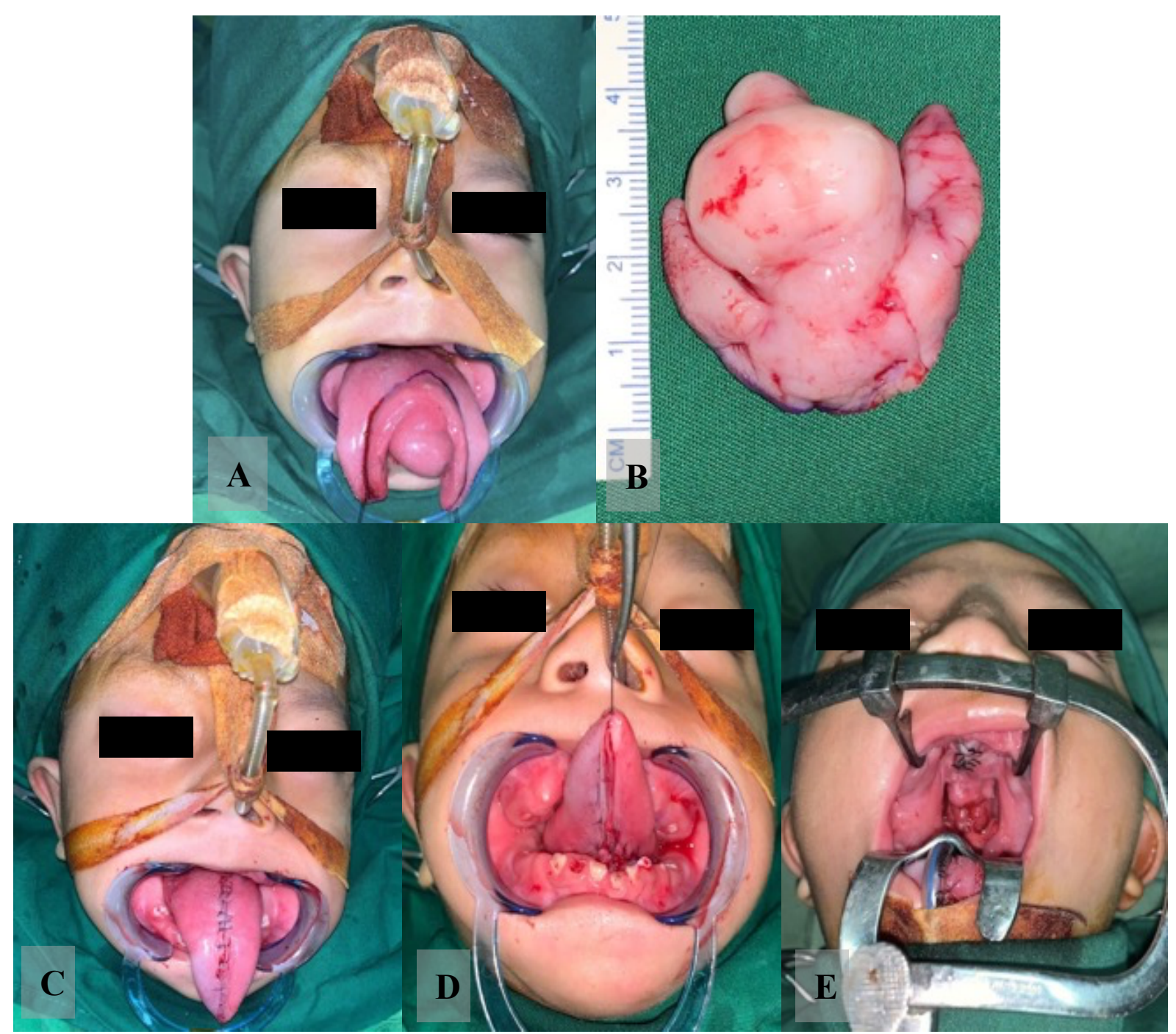

Figure 3. Intraoperative picture of the A) Incision Design B) Excised sublingual mass measuring $4 \mathrm{~cm} \mathrm{x} 3 \mathrm{~cm}$ in size, C)

Primary closure of the tongue defect in layers including muscular and mucosa repair, D) The frenulum and the sublingual ventral defect was closed in a Z-Plasty fashion, E) Post excisional biopsy palatal mass. 




Figure 4. One month after the operation.

\section{DISCUSSION}

The development of the tongue begins around the 4 th week of embryogenesis. It rises from the median swelling, tuberculum impar of the floor of the pharynx, and two lateral lingual swellings joining the central structure. The lateral lingual systems grow and cover the tuberculum impar to form the anterior two-thirds of the tongue. When there is any disturbance during this process, the tip of the tongue is divided longitudinally for a specific distance results in a cleft tongue/bifid tongue. Various terms such as accessory tongue, double tongue, and supernumerary tongue are used to define the bifid tongue. Review articles of 37 cases by Hiradfar et al. (2015) described that most cases are female $(62 \%)$ and associated with cleft palate $(43 \%)$, which is as depicted in this case report (1).

The congenital bifid tongue is mostly syndromic. Non-syndromic cases are usually caused by mechanical interference from a congenital neoplasm development during tongue embryogenesis. It is believed that the benign neoplasm is derived from aberrant mesenchymal cells, and its growth leads to hypoplasia and the formation of the cleft tongue. Lingual hamartoma (64\%) was described as the most common congenital neoplasm associated with the bifid language, followed by teratoma (27\%) and fibro lipoma (9\%) (3). This case is unique in which histopathological examination of the masses showed Pseudoepitheliomatous Hyperplasia $(\mathrm{PEH})$ of the sublingual and palate tissue; thus, this finding is rarely stated in the literature.

Pseudoepitheliomatous hyperplasia $(\mathrm{PEH})$ is a reactive epithelial proliferation response to various conditions such as infections, neoplasia, inflammation, and trauma. It is characterized by hyperplasia of epidermis and adnexal epithelium and often mimics squamous cell carcinoma (SCC) histological features. $\mathrm{PEH}$ is a reactive process to an external stimulus or underlying disease process as a physiological response to several forms of skin damage. It can be seen in various conditions such as Blastomycosis, Granular cell tumor (GCT), oral malignant melanoma, and epulis, and the latter is described in the CT Scan finding of this patient (4). Congenital epulis is a sporadic benign tumor of the oral cavity which the exact etiology remains unclear, although hormonal theory is proposed. Histopathology features fibrous connective tissue and hyperplastic epithelium, with few cases exhibiting PEH. Although benign, immediate surgical intervention is required because it may lead to mechanical airway obstruction (5).

Disruption of these facial prominences development can cause various facial anomalies. Following the formation of the primary palate, the secondary palate developed above the tongue during the 7th to 10th week of embryonal life via the midline fusion of maxilla palatal shelves. The palatal shelves will initially obliquely project and caudally grow down the oronasal cavity alongside the tongue $(2,6)$. Any space-occupying lesions over the dorsal aspect of the tongue will interfere with the fusion of palatal shelves, causing cleft of the secondary palate in a newborn $(2,7)$. It is not surprising that the reported case is associated with secondary palate cleft and bifid tongue as a sequela of the congenital masses.

There is no consensus of the timing of surgery, management, and surgical technique of bifid tongue due to the infrequency cases. Surgical excision of lingual or palatal masses is still the choice of treatment. It can be a life-saving surgery based on the degree of respiratory difficulties caused by obstruction (8). The study from Haghigi et al. (2004) recommended that the 
surgical management of the bifid tongue and cleft be conducted before the speech development to prevent speech disorders (9). In this case report, the correction was performed in stages because of the difficulty in reconstructing the tongue and palate simultaneously and reduce the risk of airway compromise due to postoperative intraoral edema and bleeding. Anticipating intraoperative and postoperative challenges in airway and desaturation necessitates preoperative care in the pediatric intensive care unit or pediatric high dependency unit.

Finally, the reconstruction goals of this case should restore swallowing, speech function, and cosmesis. After the first corrective surgery, the patient was referred to a speech therapist for tongue function rehabilitation, enhancing surgical outcomes, especially in articulation. Long-term regular follow-ups are needed to assess the development and functional outcomes.

\section{SUMMARY}

Congenital bifid tongue with cleft palate is a very rare malformation with different variations. Early repair of the bifid tongue is essential to assist the baby in adapting to speech and swallowing as they grow. A multidisciplinary approach, well-planned staged operations, and rehabilitation are required to achieve favorable outcomes.

\section{Correspondence regarding this article should be addressed to: \\ I Gusti Ayu Putri Purwanthi \\ Division of Plastic Reconstructive and Aesthetic Surgery, Department of Surgery, Faculty of Medicine Udayana University / Sanglah General Hospital Bali. \\ Denpasar, Indonesia. \\ E-Mail: purwanthiputrigmail.com}

\section{REFERENCES}

1. Hiradfar M, Bakhshaee $M$, Shojaeian R, Zabolinejad N, Forghani M, Mirhosseini F. Accessory tongue: Classification and report of a case. Int J Pediatr Otorhinolaryngol [Internet]. 2015;79(8):1175-9. Available from:

http://dx.doi.org/10.1016/j.ijporl.2015.04.0 29

2. Lee JY, Mohd Zainal H, Mat Zain MA Bin. Bifid Tongue and Cleft Palate With and Without a Tessier 30 Facial Cleft: Cases of
Rare Congenital Anomalies and a Review of Management and Literature. Cleft PalateCraniofacial J. 2019;56(9):1243-8.

3. Takagi Y, Machida J, Sato H, Sakuma H, Noda H, Ohiwa I. Congenital bifid tongue with lingual hamartoma: A case report and review of the literature. J Oral Maxillofac Surgery, Med Pathol [Internet]. 2016;28(2):133-7. Available from: http://dx.doi.org/10.1016/j.ajoms.2015.09. 001

4. Hiebert JC, Johnson AB, Tran $\mathrm{HH}, \mathrm{Yu} \mathrm{Z}$, Glade RS. Congenital tongue mass with concomitant cleft palate and bifid tongue: A case report and review of the literature. Cleft Palate-Craniofacial J. 2016;53(2):245-8.

5. Eghbalian F, Monsef A. Congenital Epulis in the Newborn, Review of the Literature and a Case Report Clinical And Laboratory Observations. J Pediatr Hematol Oncol. 2009;31(3):198-9.

6. Sadler T, Langman J. Medical Embryology. Philadelphia, PA: Wolters Kluwer Health/Lippincott Williams \& Wilkins; 2012.

7. Vasudevan V, Chavva P, Devaiah D, Venkatappa M, Shrihari TG, Viswanath D. Nonsyndromic Accessory Tongue in a Patient with Cleft Palate: A Rare Case Report. 2014;(January 2013):218-20.

8. Bonet C, Peñarrocha-Oltra D, Minguez JM, Vera-Sirera B, Peñarrocha-Diago $M$, Peñarrocha-Diago M. Oral teratomas: A report of 5 cases. J Oral Maxillofac Surg [Internet]. 2012;70(12):2809-13. Available from:

http://dx.doi.org/10.1016/j.joms.2012.01.0 28

9. Haghighi K, Milles M, Cleveland D, Ziccardi V. Epignathnus Teratoma with Bifid Tongue and Median Glossal Salivary Mass: Report of a Case. J Oral Maxillofac Surg. 2004;62(3):379-83. 